\title{
Efektivitas Bio-matriconditioning Benih Pratanam dengan Campuran Endo-rizobakteri dalam Meningkatkan Viabilitas dan Vigor Benih Cabai (Capsicum annuum L.)
}

\author{
Gusti Ayu Kade Sutariati ${ }^{1 *}$, Tresjia Corina Rakian ${ }^{1}$, Muhidin' ${ }^{1}$, Andi Khaeruni ${ }^{2}$, Dewi Nurhayati \\ Yusuf ${ }^{3}$, Gusti Ngurah Adhi Wibawa ${ }^{4}$, dan La Mudi ${ }^{5}$ \\ 1Jurusan Agroteknologi Fakultas Pertanian Universitas Halu Oleo, Kendari \\ 2Jurusan Proteksi Tanaman Fakultas Pertanian Universitas Halu Oleo Kendari, Sulawesi \\ Tenggara \\ 3Jurusan Ilmu tanah Fakultas Pertanian Universitas Halu Oleo Kendari, Sulawesi Tenggara \\ ${ }^{4} J u r u s a n$ Statistik, Fakultas Matematika dan Ilmu Pengetahuan Alam, Universitas Halu Oleo \\ Kampus Hijau Bumi Tridharma Jl. HEA Mokodompit Anduonohu Kendari Sulawesi Tenggara \\ 93232 \\ ${ }^{5}$ Program Studi Budidaya Tanaman Perkebunan Politeknik Pertanian Negeri Samarinda, \\ Kalimantan Timur \\ *Alamat korespondensi: sutariati69@yahoo.co.id
}

\begin{tabular}{|c|c|}
\hline INFO ARTIKEL & ABSTRACT/ABSTRAK \\
\hline Diterima: $13-11-2021$ & \\
\hline $\begin{array}{lr}\text { Direvisi: } & 05-01-2022 \\
\text { Dipublikasi: } 23-01-2022\end{array}$ & $\begin{array}{l}\text { The Effectiveness of Pre-Planted Seed Bio-matriconditioning Using A Mixture } \\
\text { of Endo-rhizobacteria in Increasing Seeds Viability and Vigor of Hot Pepper } \\
\text { (Capsicum annuum L.) }\end{array}$ \\
\hline
\end{tabular}

Keywords:

Bacillus sp. CKD061,

Endophytic bacteria,

Pseudomonas sp.

SWRIIB02,

Pseudomonas sp. PG01,

Rhizobacteria

The use of high quality seeds is an important prerequisite in plant cultivation in order to produce plants which are able to produce optimally. This study aimed to evaluate the effectiveness of pre-planting seed bio-matriconditioning treatment using a mixture of endo-rhizobacteria in increasing seeds viability and vigor of hot pepper. This research was conducted at the Agrotechnology Laboratory of the Agronomy Unit from March to April 2021. The study was arranged using a completely randomized design consisting of 8 treatments with 3 replications. Observational data were tabulated and analyzed using analysis of variance, the results of the analysis which showed a significant effect were followed by DMRT $\alpha=0.05$. The variables observed in this study used the viability and vigor parameters of the seeds. The results showed that the preplanted seeds bio-matriconditioning treatment was able to increase the viability and vigor of hot pepper seeds. Seed bio-matriconditioning treatment with a mixture of Bacillus sp. CKD061 + Pseudomonas sp. SWRIIB02 gave the best results on the observation of seed viability and vigor followed by seeds bio-matriconditioning treatment using a mixture of Bacillus sp. CKD061 + Pseudomonas sp. SWRIIB02 + Pseudomonas sp. PG01. The increase in seed vigor (using seed germination indicators) in both treatments reached $100 \%$ and $81 \%$, respectively, compared to the control.

Kata Kunci:

Bacillus sp. CKD061,

Bakteri endofit,

Pseudomonas sp.

SWRIIB02,

Pseudomonas sp. PG01,

Rizobakteri

Penggunaan benih bermutu tinggi merupakan prasyarat penting dalam budidaya tanaman agar dihasilkan tanaman yang mampu berproduksi secara optimal. Penelitian ini bertujuan mengevaluasi efektivitas perlakuan biomatriconditioning pratanam menggunakan campuran endo-rizobakteri dalam meningkatkan viabilitas dan vigor benih cabai. Penelitian ini dilaksanakan di Laboratorium Agroteknologi Unit Agronomi pada bulan Maret sampai dengan April 2021. Penelitian disusun menggunakan rancangan acak lengkap yang 
terdiri atas 8 perlakuan dengan 3 ulangan. Data hasil pengamatan ditabulasi dan dianalisis dengan menggunakan analisis varian, hasil analisis yang menunjukkan pengaruh nyata dilanjutkan dengan uji Duncan Multiple Range Test $\alpha=0,05$. Pengamatan terhadap viabilitas dan vigor benih cabai menggunakan peubah daya berkecambah, potensi tumbuh maksimum, indeks vigor, keserempakan tumbuh, kecepatan tumbuh relatif, T50, bobot kering kecambah normal dan laju pertumbuhan kecambah. Hasil penelitian menunjukkan bahwa perlakuan bio-matriconditioning benih pratanam mampu meningkatkan viabilitas dan vigor benih cabai. Perlakuan biomatriconditioning benih dengan campuran isolat Bacillus sp. CKD061 + Pseudomonas sp. SWRIIB02 memberikan hasil terbaik terhadap viabilitas dan vigor benih, kemudian diikuti perlakuan bio-matriconditioning benih dengan campuran isolat Bacillus sp. CKD061 + Pseudomonas sp. SWRIIB02 + Pseudomonas sp. PG01. Peningkatan vigor benih (menggunakan indikator daya berkecambah) pada perlakuan tersebut masing-masing mencapai $100 \%$ dan $81 \%$ dibandingkan dengan kontrol.

\section{PENDAHULUAN}

Cabai (Capsicum annuum L.) merupakan salah satu tanaman hortikultura yang banyak diminati masyarakat Indonesia karena rasanya yang khas. Meskipun cabai banyak diminati oleh masyarakat, cabai memiliki permasalahan dalam budidayanya di antaranya masalah dormansi fisiologis pada benih cabai dan tingginya intensitas serangan hama dan penyakit. Hal ini tentunya berdampak terhadap penurunan produksi tanaman cabai. Oleh karena itu, diperlukan input teknologi yang ramah lingkungan berupa perlakuan bio-matriconditioning pratanam menggunakan campuran endo-rizobakteri. Perlakuan bio-matriconditioning benih merupakan salah satu teknik invigorasi benih (peningkatan vigor benih) dengan tujuan untuk meningkatkan keseragaman dan keserempakan tumbuh benih dengan mengintegrasikan bahan matrik dan agens hayati yang dapat meningkatkan viabilitas dan vigor benih, sekaligus memacu pertumbuhan tanaman. Ozbay (2018) menyatakan bahwa teknik invigorasi benih adalah salah satu metode yang efektif untuk meningkatkan pemunculan dan keseragaman benih yang mengarah pada kekuatan tumbuh dan peningkatan hasil tanaman. Penggunaan matriconditioning benih yang diintegrasikan dengan agens hayati telah terbukti mampu meningkatkan viabilitas dan vigor benih (Sutariati dkk., 2014; Sutariati et al., 2016; Sutariati et al., 2018), mengendalikan penyakit tanaman (Ilyas et al., 2015) sekaligus meningkatkan hasil tanaman (Sutariati et al., 2018).
Penggunaan matriconditioning benih ini dintegrasikan dengan agens hayati berupa bakteri endofit dan rizobakteri. Bakteri endofit mampu berperan dalam meningkatkan perkecambahan benih. Hal ini dikarenakan bakteri endofit mampu memproduksi hormon tumbuh berupa IAA yang dapat berperan dalam merangsang perkecambahan benih (Mukherjee et al., 2017; La Fua et al., 2019; Chaves et al., 2019; Sutariati et al., 2020a). Selain itu, bakteri endofit juga terbukti mampu melarutkan fosfat dan memfiksasi nitrogen (Zhu and She, 2018; Sutariati et al., 2020b). Lebih lanjut dilaporkan bahwa bakteri endofit juga mampu berperan sebagai agens pengendali hayati karena mampu menghasilkan enzim ekstraseluler yang dapat berperan melindungi benih dari patogen terbawa benih (Li et al., 2020; Khan et al., 2020).

Selain bakteri endofit, rizobakteri juga terbukti mampu berperan sebagai pemacu pertumbuhan tanaman karena dapat menghasilkan hormon tumbuh, mampu melarutkan fosfat dan juga mampu memfiksasi nitrogen (Guyasa et al., 2018; Sutariati et al., 2018a; Liu et al., 2021). Penggunaan agens hayati secara mandiri telah terbukti efektif dalam meningkatkan viabilitas dan vigor benih, meningkatkan pertumbuhan dan hasil tanaman serta berperan sebagai agens pengendali hayati (Sutariati et al., 2018b). Ryan et al. (2008), mengemukakan bahwa beberapa bakteri endofit dan rizobakteri dapat merangsang pertumbuhan langsung melalui sintesa senyawa yang membantu penyerapan nutrien dari lingkungannya termasuk sintesis asam indol asetat dan giberelin. Liu et al. (2021) melaporkan bahwa bakteri penghasil IAA dan GA mampu memacu 
perkecambahan benih sekaligus mendorong pemunculan tunas. Lebih lanjut dilaporkan bahwa inokulasi campuran $\mathrm{BPF}+$ Azotobacter sp. + Azospirilum sp. mampu meningkatkan indeks vigor benih bila dibandingkan dengan kontrol (Susiasih \& Widawati, 2017).

Aplikasi konsorsium mikroba lebih mampu meningkatkan pertumbuhan tanaman dibandingkan dengan perlakuan tunggal (Olanrewaju \& Babalola, 2019). Saputra dkk. (2020) melaporkan bahwa, penggunakan campuran agens hayati juga mampu meningkatkan daya berkecambah benih sekaligus mampu mematahkan dormansi benih cabai rawit. Lebih lanjut dilaporkan bahwa aplikasi konsorsium endo-rizobakteri mampu meningkatkan viabilitas dan vigor benih padi (Mudi dkk., 2021, Sutariati et al., 2021). Berdasarkan uraian tersebut, maka perlakuan bio-matriconditioning benih pratanam menggunakan campuran endo-rizobakteri perlu dilakukan guna meningkatkan viabilitas dan vigor benih cabai. Penelitian ini bertujuan menguji efektivitas perlakuan bio-matriconditioning pratanam menggunakan campuran endo-rizobakteri dalam meningkatkan viabilitas dan vigor benih cabai.

\section{BAHAN DAN METODE}

Penelitian ini dilakukan di Laboratorium Agroteknologi Unit Agronomi Fakultas Pertanian Universitas Halu Oleo, Kendari mulai bulan Maret sampai dengan April 2021. Bahan yang digunakan dalam penelitian ini adalah benih cabai, isolat rizobakteri Bacillus sp. CKD061 dan Pseudomonas sp. PG01, isolat bakteri endofit Pseudomonas sp. SWRIIB02, alkohol 70\%, Trypthic Soy Agar (TSA), protease peptone, $\mathrm{KH}_{2} \mathrm{PO}_{4}, \mathrm{MgSO}_{4} .7 \mathrm{H}_{2} \mathrm{O}$, gliseroll, spiritus, tissue, aluminium foil, agar, natrium hipoklorit, plastik wrap, kertas label dan arang sekam. Alat yang digunakan dalam penelitian ini adalah bak kecambah, hand sprayer, timbangan analitik, oven, jarum ose, cawan petri, bunsen, gelas ukur, botol scott, desikator, shaker, stirrer, autoclave, gelas kimia, laminar air flow cabinet (LAFC), erlenmeyer dan alat tulis menulis. Penelitian disusun menggunakan rancangan acak lengkap (RAL) dengan 3 ulangan dan 8 perlakuan yaitu: kontrol (A0), biomatriconditioning Bacillus sp. CKD061 (A1), biomatriconditioning Pseudomonas sp. SWRIIB02 (A2), bio-matriconditioning Pseudomonas sp. PG01 (A3), bio-matriconditioning Bacillus sp. CKD061 + Pseudomonas sp. SWRIIB02 (A4), biomatriconditioning Bacillus sp. CKD061 +
Pseudomonas sp. PG01 (A5), bio-matriconditioning Pseudomonas sp. SWRIIB02 + Pseudomonas sp. PG01 (A6), dan bio-matriconditioning Bacillus sp. CKD061 + Pseudomonas sp. SWRIIB02 + Pseudomonas sp. PG01 (A7), sehingga secara keseluruhan terdapat 24 unit percobaan.

Isolat endo-rizobakteri diperbanyak dengan media TSA untuk kelompok Bacillus sp. dan media King'B untuk kelompok Pseudomonas sp. Media TSA dibuat dengan menimbang $40 \mathrm{~g}$ TSA selanjutnya dilarutkan dalam aquades $1000 \mathrm{ml}$ dan direbus hingga mendidih selama \pm 20 menit. Sementara media King'B (Pres et al., 2001) dibuat dengan menimbang $20 \mathrm{~g}$ protease peptone, 1,5 g $\mathrm{K}_{2} \mathrm{HPO}_{4}, \quad 1,5$ $\mathrm{MgSO}_{4} .7 \mathrm{H}_{2} \mathrm{O}, 15 \mathrm{~g}$ agar dan $15 \mathrm{ml}$, selanjutnya dicampurkan ke dalam $1000 \mathrm{ml}$ aquades dan direbus hingga mendidih selama \pm 20 menit. Setelah mendidih media dimasukkan ke dalam botol scott dan disterilkan menggunakan autoclave (Suhu $121^{\circ} \mathrm{C}$, tekanan $1 \mathrm{~atm}$, selama 20 menit). Selanjutnya, media TSA dan King's B dituang dalam cawan petri dengan ketebalan $\pm 0,5 \mathrm{~cm}$ secara aseptik dalam $L A F C$ (Laminar Air Flow Cabinet) kemudian didinginkan dan siap digunakan. Isolat endo-rizobakteri selanjutnya ditumbuhkan dalam media padat dan diinkubasi selama 48 jam. Koloni bakteri yang tumbuh disuspensikan dalam aquades steril hingga mencapai kerapatan populasi $10^{9} \mathrm{cfu} / \mathrm{ml}$. Sebelum diinokulasi bakteri endofit dan rizobakteri, benih cabai didisinfeksi dengan natrium hipoklorit 5\% selama 5 menit, kemudian dibilas dengan aquades steril sebanyak 3 kali lalu dikering-anginkan dalam LAFC (Mudi dkk., 2021). Perlakuan benih dilakukan dengan menggunakan metode bio-matriconditioning benih dengan perbandingan $5 \mathrm{~g}$ benih : $10 \mathrm{~g}$ bahan matriks serbuk arang sekam: 7,5 ml suspensi bakteri (perbandingan komposisi berdasarkan hasil penelitian pendahuluan). Selanjutnya benih cabai diinkubasi selama 24 jam. Setelah perlakuan, benih kembali dikering-anginkan dalam $L A F C$. Selanjutnya untuk uji viabilitas dan vigor benih sebanyak 50 butir benih dikecambahkan dalam baki yang berisi arang sekam steril, untuk selanjutnya dilakukan pengamatan terhadap parameter viabilitas dan vigor benih.

Variabel yang diamati pada penelitian ini menggunakan parameter viabilitas benih dan vigor benih yaitu sebagai berikut:

\section{Potensi Tumbuh Maksimum (PTM).}

Potensi tumbuh maksimum

menggambarkan viabilitas total benih (Sadjad dkk., 
1999), dihitung berdasarkan jumlah benih berkecambah pada hari terakhir pengamatan (14 hst) dengan rumus:

$$
\mathrm{PTM}=\frac{\sum \text { benih berkecambah }}{\sum \text { benih yang ditanam }} x 100
$$

\section{Daya Berkecambah (DB).}

Daya berkecambah (\%) menggambarkan viabilitas potensial benih (Sadjad dkk., 1999), dihitung berdasarkan persentase kecambah normal pada hari terakhir pengamatan (14 hst) dengan rumus:

$$
\mathrm{DB}=\frac{\sum \text { benih kecambah normal }}{\sum \text { benih yang ditanam }} x 100
$$

\section{Keserempakan Tumbuh (KST).}

Keserempakan tumbuh (\%) menggambarkan vigor benih, dihitung berdasarkan persentase kecambah normal pada hari antara hitungan pertama (7 hst) dan kedua (14 hst), dengan rumus:

$$
\mathrm{KST}=\frac{\sum \text { kecambah hari antara KNI \& KNII }}{\sum \text { benih yang ditanam }} x 100
$$

\section{Indeks Vigor (IV).}

Indeks vigor (\%) diamati dengan menghitung persentase kecambah normal pada hari hitungan I. Persentase kecambah normal hari hitungan I, diamati pada hari ke-7 dihitung dengan rumus:

$$
\mathrm{IV}=\frac{\sum \text { kecambah normal hitungan I }}{\sum \text { benih yang ditanam }} x 100
$$

\section{Kecepatan Tumbuh Relatif (KCT-r).}

Kecepatan tumbuh (\%/etmal) dihitung berdasarkan akumulasi kecepatan tumbuh setiap hari melalui pengamatan persentase kecambah normal perhari. Pada benih cabai, KCT relatif dihitung melalui perbandingan nilai KCT dengan KCT maksimum yang diperoleh dari asumsi bahwa saat hitungan I pertumbuhan kecambah normal mencapai $100 \%$.

\footnotetext{
Keterangan:

$\mathrm{t} \quad=$ waktu pengamatan

$\mathrm{N}=\%$ kecambah normal per pengamatan

tn = waktu akhir pengamatan
}

$$
\begin{aligned}
\text { KCT }-\mathrm{r} & =\frac{\mathrm{KCT}}{\mathrm{KCT} M a x} \\
\mathrm{KCT} & =\sum_{0}^{\operatorname{tn} \frac{N}{t}} \\
\text { KCT Max } & =\frac{100}{\Sigma \text { hari hitungan } \mathrm{I}}
\end{aligned}
$$

Bobot Kering Kecambah Normal (BKKN). Menggambarkan vigor benih yang ditunjukkan dengan kemampuan mengoptimalkan cadangan makanan dalam benih ke dalam bentuk akumulasi bobot kering kecambah. Pengujian dilakukan di akhir pengamatan. Seluruh kecambah normal dicabut, dibungkus dengan aluminium foil dan dikeringkan dalam oven dengan suhu $60^{\circ} \mathrm{C}$ selama 3 hari, setelah itu dimasukkan ke dalam desikator \pm 30 menit kemudian ditimbang.

Laju Pertumbuhan Kecambah (LPK). Menggambarkan vigor benih, dihitung berdasarkan hasil BKKN dengan rumus:

$$
\mathrm{LPK}=\frac{\text { Bobot kering kecambah }}{\sum \text { Kecambah normal }}
$$

Waktu mencapai $50 \%$ perkecambahan ( $\left.\mathrm{T}_{50}\right) . \mathrm{T}_{50}$ (hari) adalah waktu yang dibutuhkan untuk mencapai $50 \%$ total pertumbuhan kecambah, pengamatan dilakukan setiap hari. Rumus $\mathrm{T}_{50}$ yaitu:

$$
\mathrm{T}_{50}=t i+\left[\frac{\mathrm{n} 50 \%-\mathrm{ni}}{\mathrm{nj}-\mathrm{ni}}\right]
$$

Keterangan:

$\mathrm{T}_{50}=$ waktu (hari) yang dibutuhkan untuk mencapai $50 \%$ total perkecambahan

ti = waktu (hari) batas bawah sebelum mencapai $50 \%$ perkecambahan

$\mathrm{n} 50=\sum$ kecambah $50 \%$ dari total perkecambahan

ni $=\sum$ kecambah batas bawah sebelum 50\% total perkecambahan

nj $=\sum$ kecambah batas atas setelah mencapai 50\% total perkecambahan

Data hasil pengamatan ditabulasi dan dianalisis menggunakan analisis ragam (ANOVA). Hasil analisis yang menunjukkan pengaruh nyata dilanjutkan dengan uji Duncan Multiple Range Test (DMRT) $\alpha=0,05$.

\section{HASIL DAN PEMBAHASAN}

Hasil penelitian menunjukkan $\begin{array}{r}\text { bahwa } \\ \text { benih }\end{array}$
$\begin{aligned} & \text { berlakuan matriconditioning } \\ & \text { menggunakan campuran endo-rizobakteri mampu } \\ & \text { meningkatkan viabilitas dan vigor benih cabai. Di }\end{aligned}$
antara perlakuan yang diuji, secara umum perlakuan
benih dengan campuran bio-matriconditioning
Bacillus sp. CKD061 + Pseudomonas sp. SWRIIB02
dan campuran 3 isolat (Bacillus sp. CKD061 +
Pseudomonas sp. SWRIIB02 + Pseudomonas sp.


PG01) menunjukkan hasil yang lebih baik dibandingkan dengan kontrol dan perlakuan lainnya dalam meningkatkan daya berkecambah dan potensi tumbuh maksimum benih. Daya berkecambah pada perlakuan tersebut masing-masing mencapai $88,0 \%$ dan $86,7 \%$. Daya kecambah cabai pada perlakuan kontrol hanya sebesar $48,0 \%$. Sementara itu pada peubah indeks vigor, selain ke-2 perlakuan tersebut, perlakuan dengan campuran Pseudomonas sp.
SWRIIB02 + Pseudomonas sp. PG01 juga menunjukkan kemampuan meningkatkan indeks vigor dibandingkan dengan kontrol (Tabel 1). Pengamatan pada peubah keserempakan tumbuh menunjukkan bahwa semua perlakuan biomatricondioning baik menggunakan isolat tunggal maupun campuran, memberikan pengaruh yang sama terhadap keserempakan tumbuh benih, kecuali kontrol (Tabel 1).

Tabel 1. Daya berkecambah, indeks vigor benih, potensi tumbuh maksimum dan keserempakan tumbuh benih cabai pada perlakuan bio-matriconditioning benih menggunakan campuran endo-rizobakteri $( \pm$ (standar eror))

\begin{tabular}{ccccc}
\hline \multirow{2}{*}{ Perlakuan } & \multicolumn{4}{c}{ Variabel Pengamatan } \\
\cline { 2 - 5 } & $\begin{array}{c}\text { Daya Berkecambah } \\
(\%)\end{array}$ & $\begin{array}{c}\text { Indeks Vigor } \\
(\%)\end{array}$ & $\begin{array}{c}\text { Potensi Tumbuh } \\
\text { Maksimum }(\%)\end{array}$ & $\begin{array}{c}\text { Keserempakan } \\
\text { Tumbuh }(\%)\end{array}$ \\
\hline A0 & $48,0 \pm 4,0 \mathrm{c}$ & $25,3 \pm 6,1 \mathrm{~d}$ & $52,0 \pm 8,0 \mathrm{~d}$ & $45,3 \pm 6,1 \mathrm{~b}$ \\
A1 & $82,7 \pm 2,3 \mathrm{ab}$ & $74,7 \pm 2,3 \mathrm{ab}$ & $92,0 \pm 4,0 \mathrm{abc}$ & $81,3 \pm 4,6 \mathrm{a}$ \\
A2 & $80,0 \pm 0,0 \mathrm{~b}$ & $64,0 \pm 0,0 \mathrm{c}$ & $88,0 \pm 0,0 \mathrm{bc}$ & $80,0 \pm 0,0 \mathrm{a}$ \\
A3 & $80,0 \pm 0,0 \mathrm{~b}$ & $69,3 \pm 2,3 \mathrm{bc}$ & $85,3 \pm 4,6 \mathrm{c}$ & $80,0 \pm 0,0 \mathrm{a}$ \\
A4 & $88,0 \pm 4,0 \mathrm{a}$ & $78,7 \pm 6,1 \mathrm{a}$ & $98,7 \pm 2,3 \mathrm{a}$ & $85,3 \pm 2,3 \mathrm{a}$ \\
A5 & $84,0 \pm 0,0 \mathrm{ab}$ & $76,0 \pm 4,0 \mathrm{ab}$ & $88,0 \pm 0,0 \mathrm{bc}$ & $84,0 \pm 0,0 \mathrm{a}$ \\
A6 & $85,3 \pm 4,6 \mathrm{ab}$ & $77,3 \pm 4,6 \mathrm{a}$ & $93,3 \pm 2,3 \mathrm{ab}$ & $85,3 \pm 4,6 \mathrm{a}$ \\
A7 & $86,7 \pm 4,6 \mathrm{a}$ & $77,3 \pm 2,3 \mathrm{a}$ & $97,3 \pm 2,3 \mathrm{a}$ & $85,3 \pm 2,3 \mathrm{a}$ \\
\hline
\end{tabular}

Keterangan: Angka-angka pada kolom yang sama yang diikuti oleh huruf yang sama menunjukkan tidak berbeda nyata pada taraf uji DMRT $\alpha=5 \%$. A0 (kontrol), A1 (bio-matriconditioning Bacillus sp. CKD061), A2 (bio-matriconditioning Pseudomonas sp. SWRIIB02), A3 (bio-matriconditioning Pseudomonas sp. PG01), A4 (bio-matriconditioning Bacillus sp. CKD061 + Pseudomonas sp. SWRIIB02), A5 (bio-matriconditioning Bacillus sp. CKD061 + Pseudomonas sp. PG01), A6 (biomatriconditioning Pseudomonas sp. SWRIIB02 + Pseudomonas sp. PG01), dan A7 (bio-matriconditioning Bacillus sp. CKD061 + Pseudomonas sp. SWRIIB02 + Pseudomonas sp. PG01)

Tabel 2. Kecepatan tumbuh relatif, T50, bobot kering kecambah normal dan laju pertumbuhan kecambah benih cabai pada perlakuan bio-matriconditioning benih menggunakan campuran endo-rizobakteri ( \pm (standar eror $))$

\begin{tabular}{ccccc}
\hline \multirow{2}{*}{ Perlakuan } & \multicolumn{4}{c}{ Variabel Pengamatan } \\
\cline { 2 - 5 } & $\begin{array}{c}\text { Kecepatan Tumbuh } \\
\text { Relatif (\%/etmal) }\end{array}$ & T50 (hari) & $\begin{array}{c}\text { Bobot Kering Kecambah } \\
\text { Normal }(\mathrm{mg})\end{array}$ & $\begin{array}{c}\text { Laju Pertumbuhan } \\
\text { Kecambah }\end{array}$ \\
\hline A0 & $6,4 \pm 0,8 \mathrm{c}$ & $6,5 \pm 0,2 \mathrm{a}$ & $11,3 \pm 2,1 \mathrm{~d}$ & $0,9 \pm 0,2 \mathrm{~b}$ \\
A1 & $18,9 \pm 0,4 \mathrm{a}$ & $3,4 \pm 0,2 \mathrm{c}$ & $30,0 \pm 2,6 \mathrm{abc}$ & $1,5 \pm 0,2 \mathrm{a}$ \\
A2 & $15,4 \pm 0,1 \mathrm{~b}$ & $3,7 \pm 0,6 \mathrm{bc}$ & $25,7 \pm 3,2 \mathrm{c}$ & $1,3 \pm 0,2 \mathrm{a}$ \\
A3 & $15,4 \pm 0,2 \mathrm{~b}$ & $4,1 \pm 0,4 \mathrm{~b}$ & $24,3 \pm 5,5 \mathrm{c}$ & $1,2 \pm 0,3 \mathrm{ab}$ \\
A4 & $19,1 \pm 0,4 \mathrm{a}$ & $3,2 \pm 0,1 \mathrm{c}$ & $33,7 \pm 2,1 \mathrm{a}$ & $1,5 \pm 0,0 \mathrm{a}$ \\
A5 & $18,6 \pm 1,2 \mathrm{a}$ & $3,5 \pm 0,2 \mathrm{bc}$ & $27,3 \pm 0,6 \mathrm{bc}$ & $1,3 \pm 0,0 \mathrm{a}$ \\
A6 & $18,8 \pm 0,7 \mathrm{a}$ & $3,6 \pm 0,1 \mathrm{bc}$ & $29,0 \pm 2,6 \mathrm{abc}$ & $1,4 \pm 0,2 \mathrm{a}$ \\
A7 & $19,1 \pm 0,8 \mathrm{a}$ & $3,5 \pm 0,5 \mathrm{bc}$ & $33,0 \pm 3,6 \mathrm{ab}$ & $1,5 \pm 0,1 \mathrm{a}$ \\
\hline
\end{tabular}

Keterangan: Angka-angka yang diikuti oleh huruf yang sama menunjukkan tidak berbeda nyata pada taraf uji DMRT $\alpha=5 \%$. A0 (kontrol), A1 (bio-matriconditioning Bacillus sp. CKD061), A2 (bio-matriconditioning Pseudomonas sp. SWRIIB02), A3 (bio-matriconditioning Pseudomonas sp. PG01), A4 (bio-matriconditioning Bacillus sp. CKD061 + Pseudomonas sp. SWRIIB02), A5 (bio-matriconditioning Bacillus sp. CKD061 + Pseudomonas sp. PG01), A6 (bio-matriconditioning Pseudomonas sp. SWRIIB02 + Pseudomonas sp. PG01), dan A7 (bio-matriconditioning Bacillus sp. CKD061 + Pseudomonas sp. SWRIIB02 + Pseudomonas sp. PG01) 
Hasil percobaan menunjukkan bahwa perlakuan bio-matriconditioning benih menggunakan campuran endo-rizobakteri juga mampu meningkatkan kecepatan tumbuh relatif, $\mathrm{T}_{50}$, bobot kering kecambah normal dan laju pertumbuhan kecambah benih cabai. Semua perlakuan benih dengan campuran isolat endorizobakteri dan bakteri tunggal Bacillus sp. CKD061 lebih mampu meningkatkan kecepatan tumbuh relatif benih cabai dibandingkan dengan kontrol, dan perlakuan tunggal lainnya. Pada peubah $\mathrm{T}_{50}$, perlakuan tunggal Bacillus sp. CKD061 dan campuran Bacillus sp. CKD061 + Pseudomonas sp. SWRIIB02 menunjukkan kemampuan yang lebih baik dalam mengurangi waktu perkecambahan dibandingkan dengan kontrol (Tabel 2).

Sementara itu pada peubah bobot kering kecambah normal, hanya isolat campuran Bacillus sp. CKD061 + Pseudomonas sp. SWRIIB02 yang lebih mampu meningkatkan BKKN dibandingkan dengan kontrol dan perlakuan lainnya. Semua isolat endorizobakteri baik tunggal maupun campuran, memberikan efek yang sama terhadap laju pertumbuhan kecambah benih cabai, yang berbeda nyata dengan kontrol (Tabel 2). Performa viabilitas dan vigor benih yang mendapat perlakuan biomatriconditioning benih menggunakan campuran endo-rizobakteri ditampilkan pada Gambar 1.

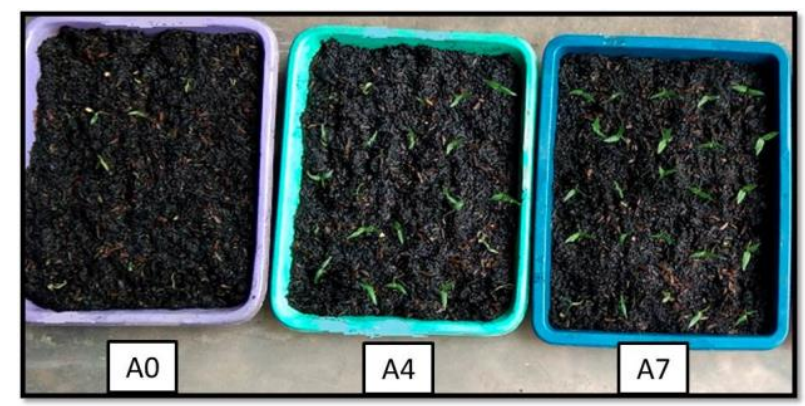

Gambar 1. Performa viabilitas dan vigor benih yang mendapat perlakuan bio-matriconditioning benih menggunakan campuran endo-rizobakteri pada pengamatan hari ke-7. A0 (kontrol), A4 ((biomatriconditioning Bacillus sp. CKD061 + Pseudomonas sp. SWRIIB02), A7 (biomatriconditioning Bacillus sp. CKD061 + Pseudomonas sp. SWRIIB02 + Pseudomonas sp. PG01)

Hasil penelitian menunjukkan bahwa perlakuan bio-matricondtioning benih pratanam menggunakan campuran endo-rizobakteri memberikan hasil yang lebih baik dalam meningkatkan viabilitas dan vigor benih cabai. Secara umum, perlakuan campuran endo-rizobakteri dengan Bacillus sp. CKD061 + Pseudomonas sp. SWRIIB02 lebih mampu meningkatkan viabilitas dan vigor benih dibandingkan dengan kontrol. Selain perlakuan tersebut, campuran 3 isolat yaitu Bacillus sp. CKD061 + Pseudomonas sp. SWRIIB02 + Pseudomonas sp. PG01 juga mampu meningkatkan viabilitas dan vigor benih cabai. Hasil penelitian ini relevan dengan hasil penelitian sebelumnya yang melaporkan bahwa campuran bakteri endofit dan rizobakteri mampu meningkatkan viabilitas dan vigor benih (Saputra dkk.., 2020; Sutariati et al., 2021). Meningkatnya viabilitas dan vigor benih cabai diduga disebabkan oleh kemampuan bakteri endofit yang dapat menghasilkan hormon tumbuh IAA (La Fua et al., 2019; Sutariati et al., 2021). Selain itu, telahd ilaporkan pula bahwa isolat rizobakteri yang digunakan juga mampu menghasilkan hormon tumbuh berupa IAA (Guyasa et al., 2018; Afa et al., 2020; Sutariati et al., 2020). Asam indol asetat (IAA) merupakan salah satu hormon pertumbuhan tanaman yang berperan penting dalam menstimulasi pertumbuhan tanaman. Hormon tumbuh yang dihasilkan bakteri endofit juga berperan dalam merangsang perkecambahan benih (Chaves et al., 2019; Sutariati et al., 2020a; Liu et al., 2021).

Peningkatan viabilitas dan vigor benih cabai juga dilaporkan oleh Mudi dkk. (2021) bahwa konsorsium endo-rizobakteri mampu meningkatkan viabilitas dan vigor benih padi gogo lokal. Perlakuan konsorsium endo-rizobakteri isolat $\mathrm{Be} 02+$ PKLK5 + Bacillus sp. CKD061 efektif meningkatkan daya berkecambah $(25,49 \%)$ dan potensi tumbuh maksimum (26,32\%) bila dibandingkan dengan kontrol. Perlakuan konsorsium endo-rizobakteri isolat $\mathrm{Be} 02+$ Bacillus sp. CKD061 efektif meningkatkan indeks vigor (36,58\%), keserempakkan tumbuh (18,75\%), T50 (20,06\%) dan panjang akar $(42,76 \%)$ bila dibandingkan dengan 
kontrol. Lebih lanjut, Saputra dkk. (2020) juga melaporkan bahwa matriconditioning serbuk bata merah + Bacillus sp. CKD061 + Pseudomonas sp. TBT214 (A6) mampu mematahkan dormansi benih cabai sekaligus meningkatkan viabilitas dan vigor benih cabai rawit kultivar Konsel 2 yang berbeda nyata dengan kontrol. Hasil yang sama juga ditunjukkan dengan inokulasi campuran BPF + Azotobacter sp. + Azospirilum sp. yang mampu meningkatkan indeks vigor benih bila dibandingkan tanpa inokulasi (kontrol) (Susiasih \& Widawati, 2017). Inokulasi benih dengan campuran Bacillus sp. CKD061 + Pseudomonas sp. SWRIIB02 mampu meningkatkan bobot kering kecambah normal. Hal ini diduga berkaitan dengan kemampuan bakteri endofit dan rizobakteri dalam menghasilkan hormon tumbuh. Peran IAA eksogen dari bakteri mampu mempercepat perkecambahan benih melalui cara memacu proses diferensiasi akar dalam membentuk rambut akar dan tunas (Herlina et al., 2017; Bhutani et al., 2018; Andriūnaitè, et al., 2021). Lebih lanjut, Astriani \& Murtiyaningsih (2018) melaporkan bahwa hormon IAA yang diproduksi oleh bakteri secara eksogen mampu mempercepat pertumbuhan tanaman. Herlina et al. (2017) melaporkan bahwa dari 16 isolat penghasil IAA dengan kemampuan sintesis IAA pada kacang hijau berpengaruh signifikan terhadap jumlah akar lateral. Isolat DM dan K1K1 memiliki efek meningkatkan pembentukan akar lateral dan dapat menjadi sumber potensial metabolit bioaktif. Selain itu, berbagai penelitian juga menunjukkan hasil yang sama seperti yang dilaporkan oleh Susiasih \& Widawati (2017) yang melaporkan aplikasi konsorsium agens hayati mampu meningkatkan panjang akar, tinggi pupus dan juga berat berat kering tanaman. Lebih lanjut dilaporkan bahwa penggunaan biomatriconditioning benih arang sekam yang dintegrasikan dengan PGPR dapat meningkatkan pertumbuhan dan hasil tanaman padi gogo (Fitriani et al., 2021).

Selain mempunyai kemampuan menghasilkan hormon tumbuh berupa IAA, bakteri endofit dan rizobakteri juga dilaporkan mampu melarutkan fosfat dan memfiksasi nitrogen ( $\mathrm{Zhu}$ and She, 2018; Sutariati et al., 2020b; Mei et al., 2021). Lebih lanjut dilaporkan bahwa bakteri endofit juga mampu berperan sebagai agens pengendali hayati karena mampu menghasilkan enzim ekstraseluler yang dapat berperan melindungi benih dari patogen terbawa benih (Li et al., 2020; Khan et al., 2020). Selain itu, rizobakteri juga dilaporkan mampu berperan sebagai agens pengendali hayati (Ilyas et al., 2015; Peter et al., 2021; Abo-Elyousr, et al., 2021; Zafar et al., 2021).

\section{SIMPULAN}

Perlakuan bio-matriconditioning benih pratanam menggunakan campuran endo-rizobakteri mampu meningkatkan viabilitas dan vigor benih cabai. Perlakuan campuran endo-rizobakteri Bacillus sp. CKD061 + Pseudomonas sp. SWRIIB02 memberikan hasil terbaik terhadap viabilitas dan vigor benih diikuti perlakuan campuran Bacillus sp. CKD061 + Pseudomonas sp. SWRIIB02 + Pseudomonas sp. PG01. Peningkatan viabilitas benih cabai (indikator daya berkecambah) pada kedua perlakuan tersebut, masing-masing mencapai $88,0 \%$ dan $86,7 \%$ dibandingkan dengan kontrol. Diperlukan penelitian lanjutan untuk menguji efektivitas biomatricondtioning benih skala lapangan dalam memacu pertumbuhan dan hasil tanaman serta pengendalian penyakit cabai.

\section{UCAPAN TERIMA KASIH}

Ucapan terimakasih kami sampaikan kepada Kementerian Riset dan Teknologi/Badan Riset dan Inovasi Nasional yang telah membiayai penelitian ini, melalui hibah Penelitian Terapan Tahun 2021.

\section{DAFTAR PUSTAKA}

Abo-Elyousr, KAM, IR Abdel-Rahim, NM Almasoudi, and SA Alghamdi. 2021. Native endophytic Pseudomonas putida as a biocontrol agent against common bean rust caused by Uromyces appendiculatus. J. Fungi. 7: 745. https://doi.org/10.3390/jof7090745.

Andriūnaitè, E, I Tamošiūnė, M Aleksandravičiūtè, D Gelvonauskienė, J Vinskienė, R Rugienius, and D Baniulis. 2021. Stimulation of Nicotiana tabacum L. in vitro shoot growth by endophytic Bacillus cereus group bacteria. Microorganisms. $\quad 9$ 9: 1893. https://doi.org/10.3390/microorganisms909189 3.

Astriani, M, dan H Murtiyaningsih. 2018. Pengukuran indole-3-acetic acid ( IAA ) pada Bacillus sp . dengan penambahan LTryptopan. Bioduscience. 2(2): 116-21. https://doi.org/10.29405/j.bes/22116-1212233.

Bhutani, N, R Maheshwari, N Monika, and SD Pooja. 2018. Optimization of IAA production by 
endophytic Bacillus spp. from Vigna radiata for their potential use as plant growth promoters. Israel Journal of Plant Sciences. 65. 10.1163/22238980-00001025.

Chaves, EID, VF Guimarães, ECG Vendruscolo, M Fonseca dos Santos, F Freitas de Oliveira, JA Cordeiro de Abreu, MP Camargo, VS Schneider, E Maltempi de Souza, LM Cruz, and E Soares de Vasconcelos. 2019. Interactions between endophytic bacteria and their effects on poaceae growth performance in different inoculation and fertilization conditions. AJCS. 13(01): 69-79.

Fitriani, Y Amri, S Bahri, and F Nadilla. 2021. Response of seed bio-invigoration with plant growth promoting rhizobacteria (pgpr) on growth and productivity of gogo rice. Bioeduscience. 5(1): 57-61. Doi: https://doi.org/10.22236/j.bes/515379.

Guyasa, IM, IGR Sadimantara, A Khaeruni, and GAK Sutariati. 2018. Isolation of Bacillus spp. and Pseudomonas fluorescens from upland rice rhizosphere and its potential as plant growth promoting rhizobacteria for local upland rice (Oryza sativa L.). Bioscience Research. 5(4): 3231-3139.

Herlina, L, KK Pukan, and D Mustikaningtyas. 2017. The endophytic bacteria producing IAA (Indole Acetic Acid) in Arachis hypogaea. Cell Biology \& Development. 1(1): 31-35. DOI: https://doi.org/10.13057/cellbioldev/v010106.

Ilyas, S, KV Asie, GAK Sutariati, and S Sudarsono. 2015. Biomatriconditioning or biopriming with biofungicides or biological agents applied on hot pepper (Capsicum annuum L.) seeds reduced seedborne Colletotrichum capsici and increased seed quality and yield. Acta Hortic. 1105 89-96.

Khan, MS, J Gao, X Chen, M Zhang, F Yang, Y Du, TS Moe, I Munir, J Xue, and X Zhang. 2020. Isolation and characterization of plant growth-promoting endophytic bacteria Paenibacillus polymyxa SK1 from Lilium lancifolium". BioMed Research International. 2020: Article ID 8650957.

La Fua, J, L Sabaruddin, LS Bande, and S Leomo. 2019. The potential of indigenous endophyte bacteria to promote local tomato growth isolated from dry land in Muna, Southeast Sulawesi, Indonesia. International Journal of Scientific \& Technology Research. 8(12): 2975-2980.
Liu, Z, X Zhang, and L Li. 2021. Isolation and characterization of three plant growthpromoting rhizobacteria for growth enhancement of rice seedling. Journal of Plant Growth Regulation. https://doi.org/10.1007/s00344-021-10393-4

Mei, C, RL Chretien, BS Amaradasa, Y He, A Turner, and S Lowman. 2021. Characterization of phosphate solubilizing bacterial endophytes and plant growth promotion in vitro and in greenhouse. Microorganisms. 9: 1935. https://doi.org/10.3390/microorganisms90919 35.

Mudi, L, GAK Sutariati, Hamriani, dan Roby. 2021. Aplikasi konsorsium endo-rizobakteri untuk meningkatkan vigor benih padi gogo lokal. Jurnal Agrotech. 11(1): 1-7.

Mukherjee, A, P Bhattacharjee, R Das, A Pal, and AK Paul. 2017. Endophytic bacteria with plant growth promoting abilities from Ophioglossum reticulatum L.[J]. AIMS Microbiology. 3(3): 596-612.

Olanrewaju, OS, and OO Babalola. 2019. Bacterial consortium for improved maize (Zea mays L.) production. Microorganisms. 7(11): 519.

Ozbay, N. 2018. Studies on seed priming in pepper (Capsicum annuum L.). In: Rakshit A., Singh H. (eds) Advances in Seed Priming. Springer.

Peter, P, K Divakaran, H Kaniyala, and AR Nair. 2021. Endophytic Bacillus spp. from Zingiber zerumbet rhizome, rhizosphere and axenic cultures: characterisation and identification of isolates with plant growth promoting activities and antagonism to soft-rot causative Pythium myriotylum. Archives of Phytopathology and Plant Protection. 1:16. doi: 10.1080/03235408.2021.1968269.

Press CM, Loper JE, and JW Kloepper. 2001. Role of iron in rhizobacteria-mediated induced systemic resistance of cucumber. Phytopathology. 91: 593-598.

Ryan, RP, K Germaine, A Franks, DJ Ryan, and DN Dowling. 2008. Bacterial endophytes: Recent developments and applications. FEMS Microbiology Letters. 278: 1-9.

Sadjad, S, E Murniati, dan S Ilyas. 1999. Parameter Pengujian Vigor Benih dari Komparatif ke Simulatif. Grasindo. Jakarta. p.185.

Saputra, J, RA Amir, N Mumin, dan GAK Sutariati. 2020. Persistensi dan pematahan dormansi benih cabai rawit lokal menggunakan teknik 
bio-invigorasi benih. J. Agrotek Tropika. 8(2): 391 - 400. ISSN: 2337-4993.

Sutariati, GAK, A Khaeruni, YB Pasolon, Muhidin and L Mudi. 2016. The effect of seed bioinvigoration using indigenous rhizobacteria to improve viability and vigor of upland rice (Oryza sativa L.) seeds. International Journal of PharmTech Research. 9: 565-573.

Sutariati, GAK, LOS Bande, A Khaeruni, Muhidin, L Mudi and RM Savitri. 2018a. The effectiveness of preplant seed bio-invigoration techniques using Bacillus sp. CKD061 to improving seed viability and vigor of several local upland rice cultivars of Southeast Sulawesi. Earth and Environmental Science. 122, 012031: 1-6.

Sutariati, GAK, Muhidin, TC Rakian, LO Afa, IM Widanta, L Mudi, GR Sadimantara, and S Leomo. 2018b. The effect of integrated application of pre-plant seed bio-invigoration, organic and inorganic fertilizer on the growth and yield of local upland rice. Bioscience Research. 15: 160-165.

Sutariati, GAK, NM Rahni, A Madiki, and IM Guyasa. 2020a. Characterization of Endophyticrhizobacteria from areca nut rhizosphere to dissolve phosphates, nitrogen fixation of IAA hormone synthesis. Pakistan Journal of Biological Sciences: PJBS. 23(3): 240-247.

Sutariati, GAK, NM Rahni, L Mudi, Nurlina, Hamriani, DN Yusuf, Muhidin, and Zahrima. 2020b. Isolation and screening test of indigenous endophytic bacteria from areca nut rhizosphere as plant growth promoting bacteria. IOP Conference Series: Earth and Environmental Science. 454(1): 012187 (2020). Sutariati, GAK, NM Rahni, A Madiki, Muhidin and GNA Wibawa. 2021. Effect of growing media composition on the growth of areca nut (Areca Catechu L.). Pakistan Journal of Biological Sciences. 24 350-6.

Sutariati, GAK, Zul'aiza, S. Darsan, LMA Kasra, S Wangadi, L Mudi. 2014. Invigorasi benih padi gogo lokal untuk meningkatkan vigor dan mengatasi permasalahan dormansi fisiologis pascapanen. Jurnal Agroteknos. 4(1): 10-17. ISSN: 2087-7706.

Zafar, S, A Bano, and TUl Hassan. 2021. Evaluation of indole-3-acetic acid deficient mutants of Pseudomonas moraviensis and its role in mitigation of salt stress in Cicer arietinum L. Pakistan Journal of Botany. 54(2): 1-10. DOI: http://dx.doi.org/10.30848/PJB2022-2(6).

Zhu and Shen. 2018. Evaluation of the plant-growthpromoting abilities of endophytic bacteria from the psammophyte Ammodendron bifolium. Canadian Journal of Mircobiology. 64(4): 253-264. 